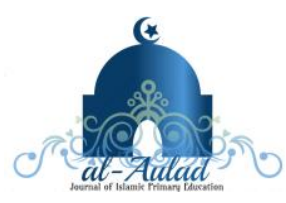

\title{
PENERAPAN STRATEGI REACT UNTUK MENINGKATKAN PEMAHAMAN SISWA PADA PEMBELAJARAN MATEMATIKA
}

\author{
Anisa Ul-Khoiriyah ${ }^{\mathbf{1}}$ \\ ${ }^{1}$ Jurusan Pendidikan Guru Madrasah Ibtidaiyah, UIN Sunan Gunung Djati, Bandung, Indonesia \\ anisa.ulkhoiriyah@yahoo.com
}

Naskah diterima: 1 Desember, 2018, direvisi: 29 Januari, 2019, diterbitkan: 31 Maret, 2019

\begin{abstract}
This research was conducted with the aim to determine students' understanding of mathematics subjects when applied to the REACT strategy in the learning process. This study used classroom action research in class V of MI Al-Musdariyah Cileunyi Bandung which amounted to 24 students. Data collection techniques in this study used tests, observations, and documentation. Learning outcomes before using the REACT strategy were obtained $25 \%$ of the test results. Teacher activities in cycle I of action 1 and 2 were 50\% and 66,67\% increased in cycle II action 1 and 2 by $83,33 \%$ and 91,67\%. Students activities in cycle I actions 1 and 2 amounted to 60,60\% and $69,70 \%$. There was an increase in cycle II of action 1 and 2 by 84,84\% and 96,97\%. The test result of students understanding using the REACT strategy increased, namely the first cycle of learning completeness classically, which was 74,98\% and in the second cycle the classical learning completeness increased to $89,58 \%$. It can be concluded that this REACT strategy can improve students understanding of mathematics subjects at MI Al-Musdariyah Cileunnyi.
\end{abstract}

Keywords: learning strategies, REACT, understanding of learning

\begin{abstract}
ABSTRAK
Penelitian ini dilakukan dengan tujuan untuk mengetahui pemahaman siswa pada mata pelajaran matematika ketika diterapkan strategi REACT pada proses pembelajaran. Penelitian ini menggunakan Penelitian Tindakan Kelas (PTK) dengan subjek penelitian siswa kelas V MI AlMusdariyah Cileunyi Bandung yang berjumlah 24 orang siswa. Teknik pengumpulan data dalam penelitian ini menggunakan tes, observasi, dan dokumentasi. Hasil pembelajaran sebelum menggunakan strategi REACT diperoleh $25 \%$ dari hasil tes. Aktivitas guru pada siklus I tindakan 1 dan 2 sebesar 50\% dan 66,67\% terjadi peningkatan pada siklus II tindakan 1 dan 2 sebesar 83,33\% dan 91,67\%. Aktivitas siswa siklus I tindakan 1 dan 2 sebesar 60,60\% dan 69,70\% terjadi peningkatan pada siklus II tindakan 1 dan 2 sebesar 84,84\% dan 96,97\%. Hasil tes pemahaman siswa menggunakan strategi REACT terjadi peningkatan yaitu siklus I ketuntasan belajar secara klasikalnya yaitu $74,98 \%$ dan pada siklus II yaitu ketuntasan belajar secara klasikal meningkat menjadi $89,58 \%$. Dapat disimpulkan bahwa strategi REACT ini dapat meningkatkan pemahaman belajar siswa pada mata pelajaran matematika di MI Al-Musdariyah Cileunyi.
\end{abstract}

Kata Kunci: pemahaman belajar, REACT, strategi pembelajaran

\section{PENDAHULUAN}

Menurut Ruseffendi matematika merupakan bahasa lambang; pengetahuan deduktif yang tidak menerima pembuktian induktif; pengetahuan tentang bentuk keteraturan serta bentuk yang terstruktur, mulai dari bagian yang tidak dimaknai ke unsur yang dapat dmaknai, ke aksioma atau postulat, dan akhirnya ke dalil (Heruman, 2013). Oleh karena itu, memahami matematika akan lebih cepat apabila didapat dari pengalaman atau siswa diajak untuk aktif bahkan mencoba langsung dalam proses pembelajaran. 
Di dunia yang terus berubah saat ini dengan persyaratan belajar seumur hidup, sangat relevan untuk bisa belajar dengan cara yang diatur sendiri. Pembelajaran mandiri diatur sebagai "The ability of students to plan, practices, and assess the learning process independently, involving continuous decisions about the cognitive, motivational, and behavioral aspects of the learning cycle process". Sejumlah penelitian menunjukkan pentingnya pembelajaran mandiri untuk prestasi akademik (Kistner, Rakoczy, Otto, \& Klieme, 2015).

Strategi pembelajaran harus diarahkan untuk memfasilitasi tercapainya kompetensi yang telah dirancang dalam dokumen kurikulum agar setiap individu mampu menjadi pembelajar mandiri seumur hidup dan pada gilirannya mereka menjadi komponen penting untuk menciptakan masyarakat belajar (Utami, 2016). Oleh karena itu, pendekatan konstruktivisme sangat berhubungan erat dengan kurikulum nasional dan pendekatan ini berkembang menjadi salah satu strategi pembelajaran yang dinamakan REACT.

Strategi REACT adalah kependekan yang menyatakan bagian-bagian yang harus dilakukan pada proses pembelajaran yaitu menghubungkan (Relating), mengalami (Experiencing), menerapkan (Applying), bekerjasama (Cooperating), dan mentranfer (Transferring) (Komalasari, 2013). Oleh karena itu, strategi REACT ini merupakan konsep pembelajaran yang mendorong siswa membuat hubungan-hubungan antara pengetahuan yang telah dimilikinya dengan penerapannya dalam kehidupan sehari-hari.

Berdasarkan hasil observasi di kelas V MI AL-Musdariyah ada beberapa permasalahan dalam pembelajaran yaitu pembelajaran didominasi oleh guru saja yang akhirnya peserta didik kurang aktif. Hal ini terjadi dikarenakan ketika hasil tes, nilai pelajaran matematika mereka tidak begitu baik dan masih dibawah KKM. Ketika guru memberikan soal tes matematika kepada peserta didik, peserta didik memberikan respon yang kurang baik dan terlihat cemas karena pemahaman materi yang kurang disaat proses pembelajaran. Berdasarkan kondisi tersebut timbulah permasalahan yang harus diteliti apakah dengan menerapkan strategi REACT dapat meningkatkan pemahaman belajar siswa kelas V MI Al-Musdariyah Cileunyi Kabupaten Bandung.

Penelitian ini didukung oleh beberapa peneliti yang relevan seperti penelitian dari Purwo, yang berjudul "Peningkatan Kemampuan Pemahaman dan Pemecahan Masalah Matematika melalui Strategi REACT". Dari hasil penelitian tersebut dapat diketahui bahwa pemahaman dan pemecahan masalah matematika peserta didik kelas eksperimen dengan menggunakan strategi REACT terdapat peningkatan yang lebih baik (Purwo, 2014).

Penelitian dari Hastuti, yang berjudul "Pengaruh Strategi REACT dan Minat Belajar terhadap Hasil Belajar Matematika Siswa SMP”. Dari hasil penelitian tersebut dapat diketahui adanya kontribusi pembelajaran dengan strategi REACT terhadap hasil belajar matematika serta adanya interaksi antara strategi pembelajaran REACT dan minat belajar terhadap hasil belajar matematika (Hastuti, 2016).

Berdasarkan Hasil Penelitian yang Relevan dapat diketahui bahwa belum ada yang meneliti mengenai Penerapan Strategi REACT untuk meningkatkan Pemahaman Konsep Matematika di MI. strategi REACT ini banyak diterapkan di sekolah menengah atas dan sekolah menengah pertama dan diterapkan di berbagai mata pelajaran. Oleh karena itu, peneliti akan menerapkan strategi REACT ini untuk meningkatkan pemahaman konsep dalam matematika di sekolah Dasar. 


\section{METODOLOGI}

Pendekatan penelitian yang dilakukan pada penelitian ini yaitu pendekatan kuantitatif dan pendekatan kualitatif. Pendekatan kuantitatif pada umumnya dilakukan secara random, penggunaan data menggunakan instrumen penelitian, analisis data bersifat kuantitatif/statistik dengan tujuan untuk menguji hipotesis yang telah ditetapkan. Sedangkan pendekatan kualitatif digunakan untuk meneliti pada kondisi obyek yang alamiah, analisis data bersifat induktif/kualitatif dan hasil penelitian kualitatif lebih menekankan makna dari pada generalisasi (Sugiyono, 2015).

Metode yang digunakan dalam penelitian ini adalah metode penelitian tindakan kelas (PTK). Penelitian ini merupakan bentuk reflektif berupa tindakan tertentu agar dapat memperbaiki praktik pembelajaran di kelas secara efektif dan efisien serta professional (Salahudin, 2015). Menurut Arikunto dalam Paizaludin (2013:33) ada empat tahapan yang lazim dilalui dalam proses tindakan kelas yaitu (1) Perencanaan (2) Pelaksanaan (3) Pengamatan dan (4) Refleksi.

Sumber data yang diteliti yaitu sumber data primer dan sumber data sekunder. Data primer ini diperoleh dari hasil pemahaman belajar siswa pada mata pelajaran matematika. Sumber data primer yaitu siswa kelas V MI Al-Musdariyah Kecamatan Cileunyi Kabupaten Bandung semester II pada Tahun ajaran 2018/2019. Sumber data sekunder merupakan data yang diperoleh dari guru wali kelas V MI Al-Musdariyah Kecamatan Cileunyi Kabupaten Bandung semester II pada Tahun ajaran 2018/2019.

Teknik pengumpulan data penelitian yaitu observasi, Observasi dalam penelitian ini dilakukan untuk memperoleh informasi kegiatan aktivitas guru dan aktivitas siswa selama proses pembelajaran. Tes, teknik tes adalah cara pengumpulan data penelitian yang dilakukan dengan melaksanakan tes terhadap sejumlah objek penelitian (Triyono, 2013: 174). Jenis tes yang akan digunakan untuk mengukur pemahaman konsep matematika siswa dalam penelitian ini yaitu tes tertulis. Dokumentasi, Dalam penelitian ini peneliti mengambil dokumentasi berupa foto saat proses pembelajaran berlangsung dengan menggunakan Strategi REACT.

Pada setiap siklus hingga akhir siklus, peneliti melakukan observasi guru dan peserta didik. Data berupa hasil observasi aktivitas guru dan siswa dianalisis menggunakan data deskriptif kualitatif selama proses pembelajaran. Hasil observasi aktivitas guru dan aktivitas siswa digunakan rumus sebagai berikut:

Keterangan :

$$
\mathrm{P}=\frac{\mathrm{F}}{\mathrm{N}} \times 100 \%
$$

$\mathrm{F}=$ Frekuensi Aktivitas yang tercapai

$\mathrm{N}=$ Jumlah Aspek yang diamati

(Rosdiana, 2014)

Hasil dari perhitungan persentase diatas dapat dikategorikan sesuai dengan tingkat penguasaannya, dan kategorinya dapat dilihat pada Tabel berikut:

Tabel 1. Kriteria Hasil Observasi

\begin{tabular}{|l|l|l|}
\hline No & \multicolumn{1}{|c|}{ Interval\% } & \multicolumn{1}{c|}{ Kategori } \\
\hline 1. & $85-100$ & Baik Sekali \\
\hline 2. & $71-84$ & Baik \\
\hline 3. & $61-70$ & Cukup \\
\hline 4. & $0-60$ & Kurang \\
\hline
\end{tabular}


Untuk mengetahui ketuntasan belajar siswa menggunakan rumus analisis ketuntasan belajar sebagai berikut:

1) Ketuntasan Belajar Secara Individu (KI)

$$
\mathrm{KI}=\frac{\text { Jumlah Jawaban benar }}{\text { jumlah skor maksimal }} \times 100
$$

2) Ketuntasan Belajar Secara Klasikal (KK)

$\mathrm{KK}==\frac{\text { Jumlah siswa yang memperoleh nilai } \geq 64}{\text { jumlah seluruh siswa }} \times 100 \%$

3) Menghitung nilai rata-rata kelas

$\mathrm{X}=\frac{\sum x}{n}$

Keterangan:

$\sum x$ : jumlah seluruh nilai siswa

$\mathrm{n} \quad$ : Jumlah siswa

(Hayati, 2013)

Panduan kemampuan pemahaman matematika peserta didik dalam penelitian ini menggunakan sebuah panduan penskoran yang diadaptasi dari Mosingila dan Wisniowska yang dikutip oleh (Susilawati, 2012) yaitu sebagai berikut:

Tabel 2. Kriteria Pemahaman

\begin{tabular}{|l|l|c|}
\hline \multicolumn{1}{|c|}{$\begin{array}{c}\text { Tingkat } \\
\text { Pemahaman }\end{array}$} & \multicolumn{1}{|c|}{ Kriteria Penilaian } & Skor \\
\hline Tidak paham & $\begin{array}{l}\text { Jawaban salah, tidak relevan atau jawaban hanya mengulang } \\
\text { pertanyaan serta jawaban kosong }\end{array}$ & 0 \\
\hline Miskonsepsi & $\begin{array}{l}\text { Jawaban menunjukkan kesalahan pemahaman yang mendasar } \\
\text { tentang konsep yang dipelajari }\end{array}$ & 1 \\
\hline $\begin{array}{l}\text { Miskonsepsi } \\
\text { sebagian }\end{array}$ & $\begin{array}{l}\text { Jawaban memberikan sebagian informasi yang benar tetapi juga } \\
\text { menunjukkan adanya kesalahan konsep dalam menjelaskannya }\end{array}$ & 2 \\
\hline Paham sebagian & $\begin{array}{l}\text { Jawaban benar dan mengandung paling sedikit satu konsep serta } \\
\text { tidak mengandung suatu kesalahan konsep }\end{array}$ & 3 \\
\hline Paham seluruhnya & Jawaban benar dan mengandung seluruh konsep ilmiah & 4 \\
\hline
\end{tabular}

\section{HASIL DAN DISKUSI}

Berdasarkan hasil penelitian yang dilakukan dilapangan tentang penggunaan strategi REACT pada mata pelajaran Matematika untuk meningkatkan pemahaman siswa diperoleh data sebagai berikut :

1. Proses Pembelajaran Sebelum Menggunakan Strategi REACT pada Mata Pelajaran

Matematika Kelas V MI Al-Musdariyah

Proses pembelajaran sebelum menggunakan strategi REACT pada mata pelajaran matematika di kelas $\mathrm{V}$ sangatlah rendah dan masih banyak siswa yang memperoleh nilai di bawah KKM sekolah yaitu 64. Pemahaman siswa sebelum menggunakan strategi REACT pada mata pelajaran matematika kelas $\mathrm{V}$ dapat dilihat dari nilai siswa yang masih dibawah KKM terdapat pada tabel 3 sebagai berikut: 
Tabel 3. Hasil Pretest Siswa Kelas V MI Al-Musdariyah

\begin{tabular}{|c|c|c|c|c|c|c|c|c|c|c|c|c|c|c|c|c|}
\hline \multirow{3}{*}{ No } & \multirow{3}{*}{ Nama Siswa } & \multicolumn{12}{|c|}{ Nomor Item Soal } & \multirow{3}{*}{$\begin{array}{l}\text { Skor } \\
\text { Total }\end{array}$} & \multirow{3}{*}{ Nilai } & \multirow{3}{*}{ Ket } \\
\hline & & \multicolumn{3}{|c|}{1} & \multicolumn{3}{|c|}{2} & \multicolumn{3}{|c|}{3} & \multicolumn{3}{|c|}{4} & & & \\
\hline & & $\mathrm{a}$ & $\mathrm{B}$ & $\mathrm{c}$ & $\mathrm{a}$ & $\mathrm{b}$ & $\mathrm{c}$ & $\mathrm{A}$ & $\mathrm{b}$ & $\mathrm{c}$ & $\mathrm{a}$ & $\mathrm{b}$ & $\mathrm{C}$ & & & \\
\hline 1. & Aditya Fauzan & 3 & 3 & 2 & 3 & 3 & 3 & 2 & 2 & 2 & 1 & 1 & 1 & 26 & 54,2 & Belum Tuntas \\
\hline 2. & Afnizar Alfarizi & 3 & 2 & 1 & 2 & 2 & 1 & 1 & 1 & 1 & 1 & 1 & 1 & 17 & 35,4 & Belum Tuntas \\
\hline 3. & Ahmad Muharromi & 2 & 3 & 3 & 2 & 3 & 3 & 2 & 2 & 2 & 1 & 1 & 1 & 25 & 52,1 & Belum Tuntas \\
\hline 4. & Arfian Yusran & 4 & 3 & 3 & 3 & 3 & 3 & 1 & 1 & 1 & 1 & 1 & 1 & 25 & 52,1 & Belum Tuntas \\
\hline 5. & Chintya Kholda S & 1 & 1 & 1 & 1 & 1 & 1 & 1 & 1 & 1 & 1 & 1 & 1 & 12 & 25 & Belum Tuntas \\
\hline 6. & Citra Cantika & 3 & 3 & 1 & 2 & 2 & 1 & 3 & 2 & 2 & 2 & 2 & 1 & 24 & 50 & Belum Tuntas \\
\hline 7. & Dandi Rustandi & 1 & 1 & 1 & 1 & 1 & 1 & 1 & 1 & 1 & 1 & 1 & 1 & 12 & 25 & Belum Tuntas \\
\hline 8. & Dearly Ardeas & 3 & 3 & 2 & 3 & 3 & 3 & 1 & 1 & 1 & 1 & 1 & 1 & 23 & 47,9 & Belum Tuntas \\
\hline 9. & Dimas Iqbal S & 4 & 4 & 4 & 4 & 4 & 4 & 4 & 2 & 2 & 1 & 1 & 1 & 35 & 72,9 & Tuntas \\
\hline 10. & Eric Maulana & 3 & 3 & 2 & 2 & 2 & 2 & 1 & 1 & 1 & 1 & 1 & 1 & 20 & 41,7 & Belum Tuntas \\
\hline 11. & Giska Hasna S & 4 & 4 & 4 & 2 & 4 & 4 & 4 & 2 & 2 & 1 & 1 & 1 & 33 & 68,7 & Tuntas \\
\hline 12. & Hafid Miftah N & 3 & 3 & 2 & 3 & 3 & 2 & 1 & 1 & 1 & 1 & 1 & 1 & 22 & 45,8 & Belum Tuntas \\
\hline 13. & Muhammad Ilham & 3 & 3 & 3 & 2 & 3 & 3 & 1 & 1 & 1 & 1 & 1 & 1 & 23 & 47,9 & Belum Tuntas \\
\hline 14. & Muhammad Aldo F & 1 & 1 & 1 & 1 & 1 & 1 & 1 & 1 & 1 & 1 & 1 & 1 & 12 & 25 & Belum Tuntas \\
\hline 15. & Muhammad Dante & 3 & 3 & 3 & 3 & 3 & 3 & 2 & 2 & 2 & 2 & 2 & 3 & 31 & 64,6 & Tuntas \\
\hline 16 & Pipit Anggraeni & 1 & 2 & 4 & 2 & 3 & 2 & 2 & 2 & 2 & 1 & 1 & 1 & 23 & 47,9 & Belum Tuntas \\
\hline 17. & Putri Ramdani & 3 & 3 & 2 & 3 & 3 & 2 & 2 & 2 & 2 & 2 & 3 & 2 & 29 & 60,4 & Belum Tuntas \\
\hline 18. & Radiansyah & 3 & 3 & 2 & 3 & 3 & 3 & 1 & 1 & 1 & 1 & 1 & 1 & 23 & 47,9 & Belum Tuntas \\
\hline 19. & Renata Nur L & 3 & 3 & 3 & 3 & 3 & 3 & 2 & 2 & 2 & 2 & 2 & 3 & 31 & 64,6 & Tuntas \\
\hline 20. & Sarah Maysa A & 4 & 4 & 4 & 4 & 4 & 4 & 3 & 2 & 2 & 2 & 3 & 2 & 38 & 79,2 & Tuntas \\
\hline 21. & Sendi Setiawan & 3 & 3 & 2 & 2 & 2 & 2 & 2 & 1 & 1 & 1 & 1 & 1 & 21 & 43,7 & Belum Tuntas \\
\hline 22. & Silvi Fitriyani & 2 & 2 & 2 & 1 & 2 & 2 & 1 & 1 & 1 & 1 & 1 & 1 & 17 & 35,4 & Belum Tuntas \\
\hline 23. & Siti Luthfiah & 2 & 2 & 2 & 2 & 2 & 2 & 1 & 1 & 1 & 1 & 1 & 1 & 18 & 37,5 & Belum Tuntas \\
\hline 24. & Vini Fitriyani & 4 & 3 & 3 & 4 & 3 & 3 & 2 & 2 & 2 & 2 & 2 & 2 & 32 & 66,7 & Tuntas \\
\hline \multicolumn{15}{|c|}{ Jumlah Nilai Seluruh Siswa } & \multicolumn{2}{|r|}{1191,6} \\
\hline \multicolumn{15}{|c|}{ Ketuntasan Belajar Klasikal } & \multicolumn{2}{|r|}{$25 \%$} \\
\hline \multicolumn{15}{|c|}{ Nilai Rata-Rata Kelas } & & 49,65 \\
\hline
\end{tabular}

a) Ketuntasan Belajar secara Individu (KI)

$$
\mathrm{KI}=\frac{\text { Jumlah Jawaban benar yang dicapai siswa }}{\text { jumlah skor maksimal }} \times 100
$$

Misalnya, untuk siswa pertama bernama aditya apakah belajarnya tuntas, maka dilakukan perhitungan sebagai berikut:

$$
\begin{aligned}
& \mathrm{KI}=\frac{\text { Jumlah Jawaban benar yang dicapai siswa }}{\text { jumlah skor maksimal }} \times 100 \\
& \mathrm{KI}=\frac{26}{48} \times 100=54,2
\end{aligned}
$$

(Hayati, 2013:153)

b) Ketuntasan Belajar secara Klasikal (KK)

$$
\begin{aligned}
& \mathrm{KK}=\frac{\text { Jumlah siswa yang memperoleh nilai } \geq 64}{\text { jumlah seluruh siswa }} \times 100 \% \\
& \mathrm{KK}=\frac{6}{24} \times 100 \%=25 \%
\end{aligned}
$$

Keterangan:

$<85 \%$ : Proses pembelajaran perlu perbaikan

$\geq 85 \%$ : Proses pembelajaran tuntas 

berikut:

Sedangkan untuk menghitung nilai rata-rata kelas dapat digunakan rumus sebagai

$$
\begin{aligned}
& X=\frac{\sum x}{n} \\
& X=\frac{\sum x}{n}=\frac{1191,6}{24}=49,65
\end{aligned}
$$

Dari persentase ketuntasan belajar klasikal dapat disimpulkan bahwa kemampuan pemahaman matematika siswa sebelum menggunakan strategi REACT sangat rendah. Dapat dilihat dari hasil tes siswa, dari 24 orang siswa hanya 6 orang siswa yang tuntas dan yang lainnya tidak tuntas.

Berdasarkan kriteria bahwa sebuah kelas dinyatakan telah tuntas belajar jika dari jumlah siswa kelas itu telah mencapai ketuntasan belajar $\geq 85 \%$. Pada hasil pretest ketuntasan belajar secara klasikal dari siswa yang memperoleh nilai $\geq 64$ hanya berjumlah 25\%, maka siswa kelas V MI Al-Musdariyah belum mencapai ketuntasan belajar. Sehingga diperlukan perbaikan terhadap proses pembelajaran.

2. Pelaksanaan Pembelajaran dengan Menggunakan Strategi REACT pada Mata Pelajaran Matematika Kelas V MI Al-Musdariyah

Tahapan-tahapan yang dilaksanakan guru dan siswa dalam proses pembelajaran menggunakan strategi REACT pada mata pelajaran matematika materi bangun ruang. Tahapan-tahapan ini sesuai dengan kependekan dari REACT itu sendiri, yaitu Relating (menghubungkan), Experiencing (mengalami), Applying (menerapkan), Cooperating (bekerjasama), dan Transferring (mentransfer).

Peningkatan aktivitas guru dan aktivitas siswa dari siklus I sampai siklus II dapat dilihat pada grafik di bawah ini. Grafik tersebut menunjukan bahwa terjadi peningkatan pada setiap tindakan sehingga persentase akhir dengan kategori baik sekali.

Hasil persentase aktivitas guru pada siklus I tindakan 1 yaitu 50\%. Hasil tersebut diperoleh berdasarkan pengamatan yang dilakukan oleh observer terhadap kegiatan guru. Dengan persentase 50\% maka dikategorikan kurang. Hasil persentase aktivitas siswa pada siklus I tindakan 1 yaitu 60,6\%. Hasil tersebut diperoleh berdasarkan pengamatan yang dilakukan oleh observer terhadap kegiatan siswa. Dengan persentase 60,6\% maka dikategorikan kurang. Berikut ini merupakan persentasi aktivitas guru dan aktivitas siswa pada siklus I tindakan 1 dapat dilihat pada grafik 1.

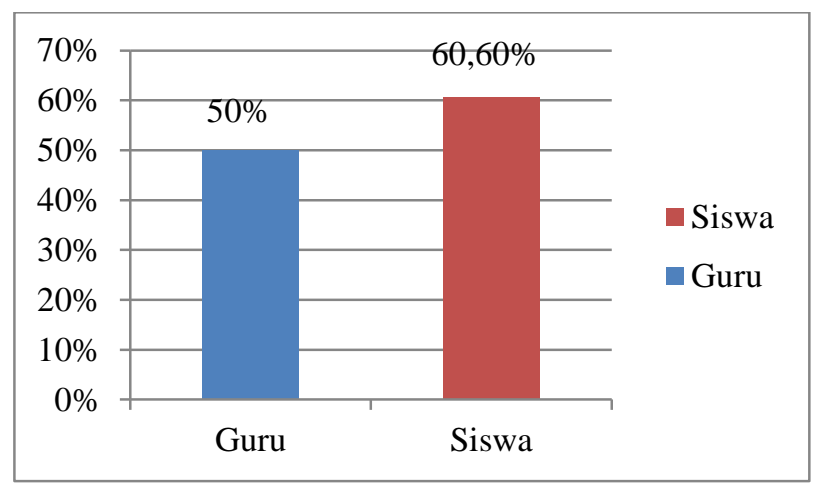

Grafik 1. Persentasi aktivitas guru dan aktivitas siswa siklus I tindakan 1

Hasil persentase aktivitas guru pada siklus I tindakan 2 yaitu $66,7 \%$. Hasil tersebut diperoleh berdasarkan pengamatan yang dilakukan oleh observer terhadap kegiatan guru. Dengan persentase $66,7 \%$ maka dikategorikan cukup. Hasil persentase aktivitas siswa pada siklus I tindakan 2 yaitu $69,7 \%$. Hasil tersebut diperoleh berdasarkan pengamatan yang 
dilakukan oleh observer terhadap kegiatan siswa. Dengan persentase 69,7\% maka dikategorikan cukup. Berikut ini merupakan persentasi aktivitas guru dan aktivitas siswa pada siklus I tindakan 1 dapat dilihat pada grafik 2.

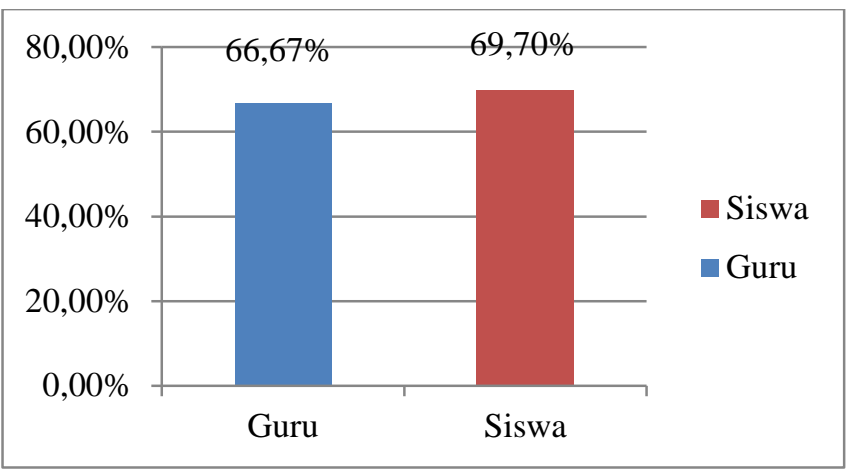

Grafik 2. Persentasi aktivitas guru dan aktivitas siswa siklus I tindakan 2

Hasil persentase aktivitas guru pada siklus II tindakan 1 yaitu 83,33\%. Hasil tersebut diperoleh berdasarkan pengamatan yang dilakukan oleh observer terhadap kegiatan guru. Dengan persentase 83,33\% maka dikategorikan baik. Hasil persentase aktivitas siswa pada siklus II tindakan 1 yaitu $84,8 \%$. Hasil tersebut diperoleh berdasarkan pengamatan yang dilakukan oleh observer terhadap kegiatan siswa. Dengan persentase 84,8\% maka dikategorikan baik. Berikut ini merupakan persentasi aktivitas guru dan aktivitas siswa pada siklus I tindakan 1 dapat dilihat pada grafik 3 .

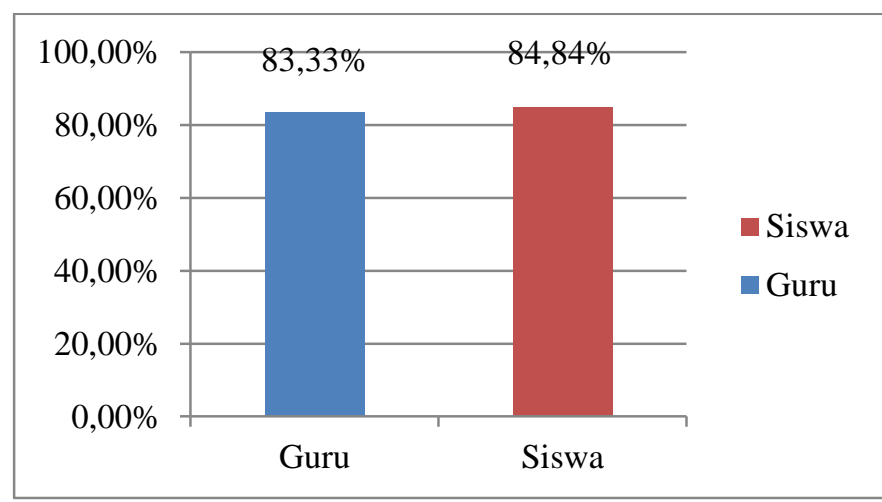

Grafik 3. Persentasi aktivitas guru dan aktivitas siswa siklus II tindakan 1

Hasil persentase aktivitas guru pada siklus II tindakan 2 yaitu 91,67\%. Hasil tersebut diperoleh berdasarkan pengamatan yang dilakukan oleh observer terhadap kegiatan guru. Dengan persentase 91,67\% maka dikategorikan baik sekali. Hasil persentase aktivitas siswa pada siklus II tindakan 2 yaitu 96,97\%. Hasil tersebut diperoleh berdasarkan pengamatan yang dilakukan oleh observer terhadap kegiatan siswa. Dengan persentase 96,97\% maka dikategorikan baik sekali. Berikut ini merupakan persentasi aktivitas guru dan aktivitas siswa pada siklus I tindakan 1 dapat dilihat pada grafik 4. 


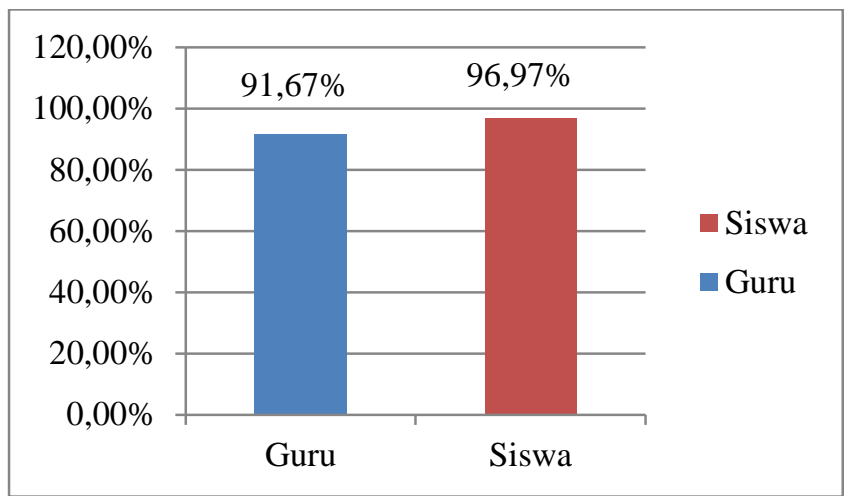

Grafik 4. Persentasi aktivitas guru dan aktivitas siswa siklus II tindakan 2

3. Pemahaman Belajar Siswa pada Pembelajaran Matematika Setelah Menggunakan Strategi REACT

Pemahaman matematika siswa dalam kegiatan belajar mengajar dengan menggunakan strategi REACT terdiri dari dua tindakan dalam satu siklus, yaitu tindakan 1 dan tindakan 2. Pada setiap tindakan dikatakan tuntas belajarnya jika melebihi nilai KKM yaitu 64, dan suatu kelas bisa disebut tuntas apabila di kelas tersebut terdapat $80 \%$ siswa yang mencapai skor lebih atau sama dengan 64.

Siklus I tindakan 1 diperoleh informasi siswa yang tuntas sebanyak 16 orang dan 8 orang siswa belum tuntas. Ketuntasan klasikal pada tindakan 1 siklus I ini sebesar 66,67\% dan nilai rata-rata kelas sebesar 68,40. Siklus I tindakan 2 diperoleh informasi siswa yang tuntas sebanyak 20 orang dan 4 orang siswa belum tuntas. Ketuntasan klasikal pada tindakan 2 siklus I ini sebesar 83,3\% dan nilai rata-rata kelas sebesar 70,49.

Berdasarkan hasil nilai ketuntasan klasikal pada tindakan 1 dan 2 siklus I, dengan hasil pada tindakan 1 sebesar $66,67 \%$ dan tindakan 2 sebesar 83,3\%, maka pemahaman matematik pada siklus I dapat dirata-ratakan sebagai berikut:

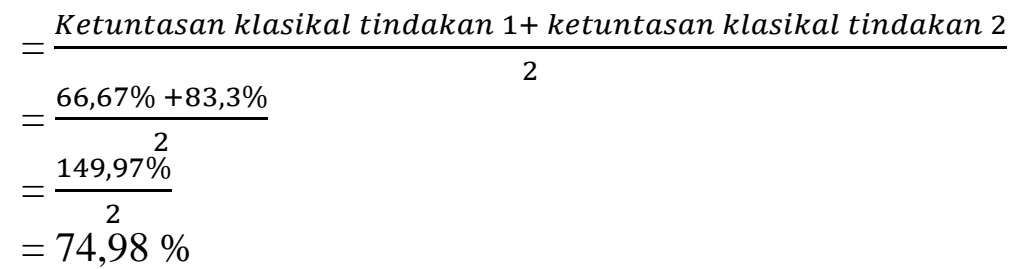

Pada siklus II tindakan 1 diperoleh informasi siswa yang tuntas sebanyak 20 orang dan 4 orang siswa belum tuntas. Ketuntasan klasikal pada tindakan 1 siklus II ini sebesar $83,33 \%$ dan nilai rata-rata kelas sebesar 74,65. Siklus II tindakan 2 diperoleh informasi siswa yang tuntas sebanyak 23 orang dan 1 orang siswa belum tuntas. Ketuntasan klasikal pada tindakan 2 siklus II ini sebesar 95,83\% dan nilai rata-rata kelas sebesar 83,34.

Berdasarkan hasil nilai ketuntasan klasikal pada tindakan 1 dan 2 siklus II, dengan hasil pada tindakan 1 sebesar 83,33\% dan tindakan 2 sebesar 95,83\%, maka pemahaman matematik pada siklus II dapat dirata-ratakan sebagai berikut:

$$
\begin{aligned}
& =\frac{\text { Ketuntasan klasikal tindakan } 1+\text { ketuntasan klasikal tindakan } 2}{2} \\
& =\frac{83,33 \%+95,83 \%}{2} \\
& =\frac{179,16 \%}{2} \\
& =89,58 \%
\end{aligned}
$$


Dibawah ini disajikan grafik peningkatan nilai rata-rata persentase ketuntasan tiap siklus pada grafik 5 Dibawah ini:

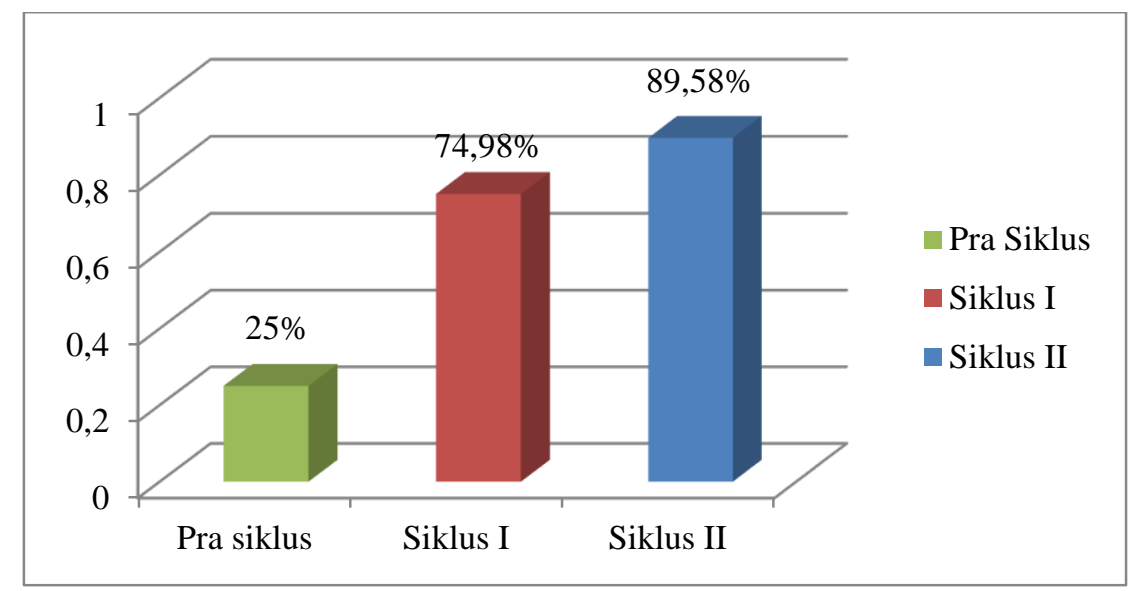

Grafik 5. Peningkatan nilai rata-rata persentase ketuntasan Belajar setiap siklus

\section{KESIMPULAN}

Berdasarkan analisis data dan hasil penelitian tentang penerapan strategi REACT untuk meningkatan pemahaman belajar siswa pada mata pelajaran matematika materi bangun ruang kubus dan balok di kelas V MI Al-Musdariyah Cileunyi Bandung, maka dapat disimpulkan pemahaman belajar matematika siswa sebelum menggunakan strategi REACT diperoleh persentase ketuntasan belajar klasikal hanya sebesar 25\%. Dari 24 orang siswa yang memperoleh nilai $\geq 64$ hanya 6 orang siswa saja. Aktivitas guru dan siswa mengalami peningkatan yang signifikan dalam setiap siklusnya. Persentase aktivitas guru pada setiap tindakan terjadi peningkatan yang signifikan. Pada siklus I tindakan 1 aktivitas guru dari 50\% meningkat menjadi $66,67 \%$ pada siklus I tindakan 2 dengan kategori kurang menjadi cukup. Selanjutnya, pada siklus II tindakan 1 aktivitas guru dari 83,33\% meningkat menjadi 91,67\% pada siklus II tindakan 2 dengan kategori baik menjadi baik sekali. Selanjutnya, untuk aktivitas siswa pun terjadi peningkatan yang signifikan pula. Aktivitas siswa pada siklus I tindakan 1 yaitu 60,60\% meningkat menjadi 69,70\% pada siklus I tindakan 2 dengan kategori kurang menjadi cukup. Sedangkan, pada siklus II tindakan 1 aktivitas siswa dari 84,84\% meningkat menjadi 96,97\% pada siklus II tindakan 2 dengan kategori baik menjadi baik sekali. Persentase ketuntasan belajar klasikal pada siklus I sebesar 74,98\%. Karena siswa yang mencapai ketuntasan belajar $\geq 64$ hanya berjumlah 74,98\%, maka siswa kelas V MI Al-Musdariyah belum mencapai ketuntasan belajar. Sehingga diperlukan perbaikan terhadap proses pembelajaran. Terjadi peningkatan pada siklus II yaitu persentase ketuntasan belajar klasikalnya sebesar 89,58\% dan siswa kelas V MI Al-Musdariyah Cileunyi Bandung sudah mencapai ketuntasan belajar. Hipotesis yang diajukan dalam penelitian telah terjawab pada simpulan akhir bahwa pemahaman konsep matematika di MI dengan menggunakan strategi REACT terbukti meningkat.

\section{DAFTAR PUSTAKA}

Hastuti, E. W. (2016). Pengaruh Strategi REACT dan Minat Belajar Terhadap Hasil Belajar Matematika Siswa SMP.

Hayati, Tuti. (2014). Evaluasi Pembelajaran. Bandung: CV. Insan Mandiri.

Heruman. (2013). Model Pembelajaran Matematika. Bandung: PT. Remaja Rodakarya. 
Kistner, S., Rakoczy, K., Otto, B., \& Klieme, E. (2015). Teaching learning strategies : The role of instructional context and teacher beliefs. Journal for Educational Research Online, 7(1), 176-197.

Komalasari, K. (2013). Pembelajaran Kontekstual Konsep dan Aplikasi. Bandung: PT Refika Aditama.

Paizaludin. (2013). Penelitian Tindakan Kelas (Classroom Action Research) Panduan Teoritis dan Praktis. Bandung: CV. Alfabeta.

Purwo, S. (2014). Peningkatan Kemampuan Pemahaman dan Pemecahan Masalah Matematika Siswa SMK Melalui Strategi Pembelajaran REACT (studi Eksperimen di SMK Negeri 52 Jakarta). Jurnal Pendidikan Dan Keguruan, 1(2), 30-40.

Rosdiana. (2014). Meningkatkan Hasil Belajar Siswa Mata Pelajaran IPS Sdn Melalui Penggunaan Media Gambar Siswa Kelas IV SDN 001 Pematang Kecamatan Batang Peranap. Jurnal Ilmu-Ilmu Sejarah, Budaya dan Sosial, 69.

Salahudin, Anas. (2015). Penelitian Tindakan Kelas. Bandung: Pustaka Setia.

Sugiyono. (2015). Metode Penelitian Pendidikan (Pendekatan Kuantitatif, Kualitatif dan $R \& D)$. Bandung: CV. Alfabeta.

Triyono, A. 2013. Manajemen Sumber Daya Manusia. Yogyakarta: Oryza.

Utami, W. S. (2016). React ( Relating , Experiencing , Applying , Cooperative, Transferring ) Strategy to Develop Geography Skills. Journal of education and practise (Vol. 7). 